\title{
COMPUTER SIMULATION OF OPTOCHEMOTRONIC SENSOR RESPONSE IN DIFFERENT MODES OF ANALYSIS
}

\author{
N. V. Masolova \\ Kharkiv national university of radioelectronics, \\ 61166, Kharkiv, Lenin ave. 14, KhNURE, BME chair., \\ phone (057) 70-21-364, E-mail: rzh@kture.kharkov.ua
}

\section{Summary \\ COMPUTER SIMULATION OF OPTOCHEMOTRONIC SENSOR RESPONSE IN DIFFERENT MODES OF ANALYSIS}

\section{N. V. Masolova}

A mathematical model of optochemotronic (OC) sensor has been developed. The model describes the OC-sensor response to the analyte in two modes of analysis: batch and flow injection, processes in the volume of OC-sensor with the working electrode modified with Langmuir-Blodgett film. This research is dedicated to revelation of parameters and processes, that are vital for the creation of OC-sensor for analysis of different biological objects and its operation in different mode of analysis.

Keywords: OC-sensor, modelling, flow injection, batch,

\section{Анотація \\ КОМП'ЮТЕРНЕ МОДЕЛЮВАННЯ РОБОТИ ОПТОХЕМОТРОНОГО (ОХ) СЕНСОРУ В РІЗНИХ РЕЖИМАХ АНАЛІЗУ}

\section{Н. В. Масолова}

Була розроблена математична модель роботи оптохемотроного (OX) сенсору. Модель описує відгук ОX-сенсору на присутність у ньому аналіту у двох режимах аналізу: проточної інжекції та дозатору, процеси, що протікають в об'ємі ОХ-сенсора з робочим електродом, модифікованим плівкою Лангмюр-Блоджетт. Дане дослідження присвячено визначенню параметрів та процесів, які є важливими для розробки ОХ-сенсора та його експлуатації в різних режимах аналізу.

Ключові слова: ОХ-сенсор, моделювання, проточна інжекція, дозатор 


\section{Аннотация \\ КОМПЬЮТЕРНОЕ МОДЕЛИРОВАНИЕ РАБОТЫ ОПТОХЕМОТРОННОГО (ОХ) СЕНСОРА В РАЗЛИЧНЫХ РЕЖИМАХ АНАЛИЗА}

\section{Н. В. Масолова}

Была разработана математическая модель работы оптохемотронного (OX) сенсора. Модель описывает отклик OX-сенсора на присутствие в нем аналита в двух режимах анализа: проточной инжекции и дозатора, процессы, протекающие в объеме OX-сенсора с рабочим электродом модифицированным пленкой Лангмюр-Блоджетт. Данное исследование посвящено определению параметров и процессов, важных для создания OX-сенсора и его эксплуатации в различных режимах анализа.

Ключевые слова: ОХ-сенсор, моделирование, проточная инжекция, дозатор

Sensors are devices that combine the selectivity and specificity of a biologically active compound with a signal transducer and an electronic amplifier [1,2]. The transducer converts the biochemical signal to an electronic one. The sensor signal is proportional to the concentration of measured analyte. The sensors are classified according to the nature of the physical transducer. Optochemotronic (OC) sensors measure the electrochemiluminescent (ECL) [3] intensity and current through working electrode due to recombination processes, which are the essential part of the ECL analysis. In case of the optochemotronic sensors the potential at the electrode is held constant while the ECL intensity and the current flow is measured. The optochemotronic sensors are reliable, relatively cheap and highly sensitive for biomedical, environment and industrial purposes.

Starting from the publication of Clark and Lyons [1], the biosensors became one of the popular and perspective trends of biochemistry. The understanding of the kinetic regularities of sensors is of crucial importance for their design. Mathematical models can explain such regularities. The general features of amperometric response was analyzed in the publications of Mell and Maloy [4]. Some later reports were also devoted to the modelling and investigation of the amperometric sensor response [5].

The goal of this investigation is to make a model allowing an effective computer simulation of optochemotronic sensor response to an analyte. The developed model is based on non-stationary diffusion equations, containing a non-linear term. The model allows to simulate the sensor action in batch and flow injection (FI) modes. In the FI analysis the sensor contacts with the ana- lyte for short time $[6,7]$ while in the batch analysis the sensor is assumed as immersed in the analyte solution of infinite volume and during long time. The digital simulation of the sensor response was carried out using the semi-implicit finite difference scheme.

The developed software was employed to generate sensor response data for analyte. The generated data can be used for the optochemotronic sensor calibration. Data needed for a sensor calibration can be produced by multiple physical experiments. However, computer simulation is much cheaper and faster than the physical experiment.

Mathematical model is based on physical model that describes processes taking place in $\mathrm{OC}$ sensor [8]. Due to peculiar properties of OC sensor's construction, namely working electrode modified with Langmuir-Blodgett (LB) film, physical model presents heterogeneous and homogeneous processes that take place in OC sensor. Charge (electron) transfer between electrode surface and molecules in immobilized LB film, intramolecular electronic excitation energy transfer (ET) between excited and ground states of immobilized reagent present the heterogeneous processes. As the homogeneous one diffusional and/or convectional ion transfer in the volume of the sensor is considered.

The analytical process starts by applying voltage to the electrodes. While ion-radicals (IR) of analyte interact with IR of reagent as the result of radical-recombination process, analytical signal, which is proportional to the concentration of analyte in tested probe, is generated by OC sensor. Charge transfer includes electron tunneling form electrode to reagent molecules through intermediate layer (subphase) consisted with amphiphilic 
molecules (necessary feature of LB technique), that are potential barrier for tunnelling electrons. Thus, charge tunnelling provides IRs creation of reagent in LB film. The excited singlet and triplet states of molecules have finite lifetime, so radiative transition of singlet states and non-radiative transition of triplet states to ground state leads to system deactivation. The deactivated molecules in ground state become IRs again due to electron transfer. ET occurs between IR of analyte and IR of reagent, deposited in the LB-film. Here ET represents resonant interaction of donor and acceptor molecules' dipole moments and proceeds by Forster mechanism, i.e. migration of electronic excitation energy from donor to acceptor that leads to distribution of excitation across LB film layers. After IR's creation IR of analyte diffuse towards the surface of the working electrode covered with reagent-electrochemiluminophore. As result of biradical recombination in LB excited singlet and triplet states are generated. After recombination IRs of analyte pass into ground state and diffuse back to the working electrode, starting new cycle of the processes described above.

Mathematical model of complex processes in OC-sensor includes two interconnected submodels:

1) model of processes on the electrode surface, modified with Langmuir-Blodgett (LB) film (electron tunneling, energy transfer, radiative deactivation);

2) model of mass transfer in the sensor volume, filled with analyte solution.

Only ion-radicals (IR) of analyte are distributed in the cell volume, because recombination processes take place at the surface of the working electrode, covered with LB film of electrochemiluminophore molecules, and reactions products will be generated in the film. If IR's of analyte are stable enough, then their diffusion time from anode to cathode is small enough in comparison with their lifetime $\tau_{\mathrm{i}}$, i.e. $\tau_{\mathrm{dif}}<<\tau_{\mathrm{i}}$. The analyte distribution in the sensor volume is described by diffusion kinetics equation:

$$
\begin{gathered}
\frac{\partial c_{g}(x, t)}{\partial t}-D_{g} \cdot \frac{\partial^{2} c_{g}(x, t)}{\partial x^{2}}=-\frac{1}{\tau_{i}} \cdot c_{i}, \\
0<x<L, 0<t \leq T,
\end{gathered}
$$

$$
\begin{gathered}
\frac{\partial c_{i}(x, t)}{\partial t}-D_{i} \cdot \frac{\partial^{2} c_{i}(x, t)}{\partial x^{2}}=\frac{1}{\tau_{i}} \cdot c_{i}, \\
0<x<L, 0<t \leq T,
\end{gathered}
$$

where $c_{g}$ - concentration of analyte molecules in ground state in the cell volume; $D_{g}$ - diffusion coefficient of analyte molecules in ground state; $c_{i}$ - concentration of analyte IR; $D_{i}$ - diffusion coefficient of analyte IR; $T$ - is full time of OCsensor operation to be analysed.

The sensor operation starts when some analyte appears in the bulk of the OC-sensor with electrodes under the applied voltage. This is used in the initial conditions $(t=0)$ :

$$
\begin{gathered}
c_{g}(x, 0)=c_{a}, \\
c_{i}(x, 0)=0 .
\end{gathered}
$$

In the FI mode the OC-sensor contacts the analyte for short time only (seconds to tens of seconds). When the analyte disappears, a buffer solution swills the analyte solution from the OCsensor volume, reducing its concentration to zero. Because analyte can't be washing out from the sensor instantly, the mass diffusion as well as the reaction still continues for some time. This is used in (3) as $c_{g}(x, 0)=0$ and in the boundary conditions $(0<t \leq T)$ given by

$$
\begin{gathered}
D_{g} \cdot \frac{\partial c_{g}(0, t)}{\partial x}=k_{s f} \cdot\left(1-e^{-t / \tau}\right) \cdot c_{g}(0, t), \\
c_{i}(0, t)=\left\{\begin{array}{cc}
c_{a}-c_{g}(0, t), & t \leq T_{f} \\
c_{a} \cdot e^{-t / T_{f}}-c_{g}(0, t), & t>T_{f},
\end{array}\right. \\
c_{g}(L, t)=\left\{\begin{array}{cc}
c_{a}-c_{i}(L, t), & t \leq T_{f} \\
c_{a} \cdot e^{-t / T_{f}}-c_{i}(L, t), & t>T_{f},
\end{array}\right. \\
k_{f i l m} \cdot c_{i}(L, t)+D_{i} \cdot \frac{\partial c_{i}(L, t)}{\partial x}=0,
\end{gathered}
$$

where $T_{f}$ - is the time of FI, i.e., the time when analyte is in the bulk of the OC-sensor; $c_{a}$ - total concentration of analyte in the cell volume; $k_{s f}$ cation-radicals formation rate at the electrode surface; $\tau$ - interelectrode capacitance charging time; $L-$ interelectrode distance; $k_{\text {film }}$ - IR recombination time at the film-solution interface.

In the batch mode of the analysis the simulating sensor remains with the analyte inside all the analysing time. Assuming $T_{f}=T$ the model ex- 
pressed by equations (1-8) may be accepted for batch analysis as well.

The current is measured as a response of a sensor in a physical experiment. The OC-sensor current (current through the working electrode) depends upon the flux of reaction product at the electrode surface. Consequently, density $J(t)$ of the sensor current, as a result of the ECL-process at time $t$, is proportional to the concentration gradient of the analyte IR at the surface of the working electrode as:

$$
J(t)=F \cdot D_{p} \cdot c_{i}(L, t),
$$

where $F$ - is Faraday constant.

The developed computer simulation software was employed to generate data for a calibration of an optochemotronic sensor. Two parameters: $T_{f}$ and $T$ depend on the mode of analysis. In FI analysis due to the disappearance of the current, time $T$ was considerably less than in batch analysis.

The results of the simulation are depicted in figure 1-3. Figure 1 shows the current dependence on $t$ in a case of batch analysis. Figure 2 presents generated sensor responses in FI analysis with $T_{f}=50 \mathrm{~s}$. Evolution of sensor current is depicted for the first 100 seconds of sensor action only because of petty change of the sensor current at greater values of time $t$. In batch analysis the maximal sensor current is the steady-state current. Figure 2 shows, that the current function $I(t)$ is not monotonous in FI analysis. Figure 3 shows the comparative curves of two modes of analysis and two types of curves, which characterize the FI mode with $T_{f}=50 \mathrm{~s}$ and $T_{f}=20 \mathrm{~s}$. As shows on figures 1-2 the intraelectrode distance influence on the maximal current, i.e. $I(t)$ rising with intraelectrode distance reduction.

As presents on fig. 3 form of the analytical signal has its individual features in different modes. Thus, in FI mode, conditions for analytical signal measuring are non-equilibrium, when neither physical processes of testing probe diluting by carrier nor chemical reactions are incompleted. The increasing peak's region of analytical signal (except the initial phase of delay) is exponential. Steady state degree doesn't depend on concentration. Hence there isn't necessity to carry out analytical reaction up to its total completion. Form of the decreasing part of the FIA peak depends on the washing out rate of test solution from the flow cell and its inertiality. In batch mode profile of increasing part of the analytical signal has exponential form too, but its free of decreasing part, i.e. there is satiety, thus batch mode doesn't provide non-equilibrium measuring conditions.

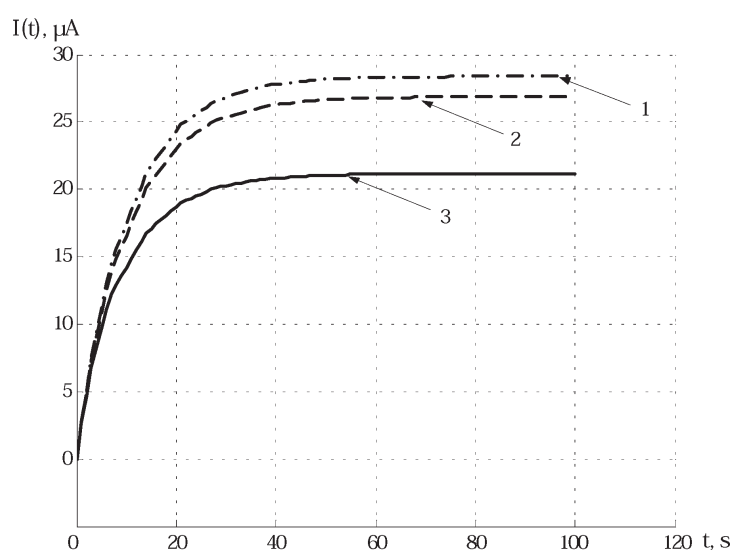

Figure 1. The current dependence on $t$ in a case of batch analysis with intraelectrode distance:

$1-40 \mu m ; 2-60 \mu m ; 3-80 \mu m$

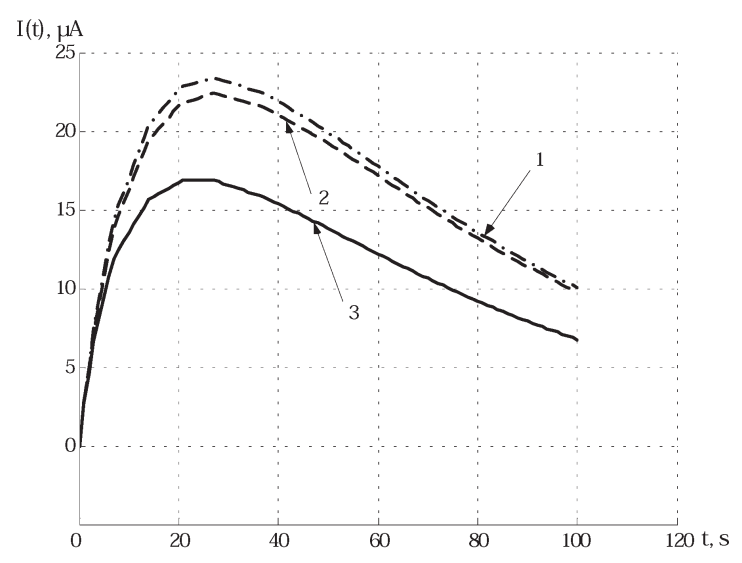

Figure 2. OC-sensor responses in FI analysis with $T_{f}=50 \mathrm{~s}$ and intraelectrode distance:

$1-40 \mu m ; 2-60 \mu m ; 3-80 \mu m$

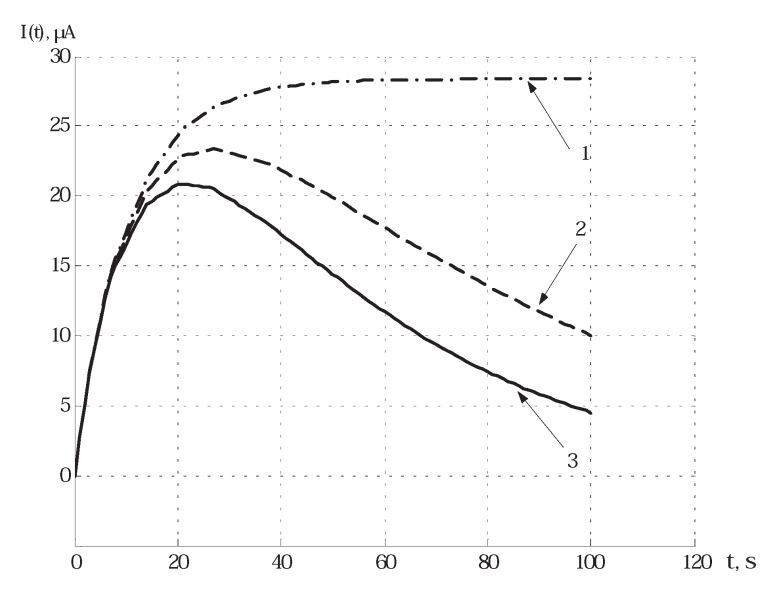

Figure 3. Comparative curves of two modes of analysis: 1 - batch; $2-$ FI with $T_{f}=50 \mathrm{~s} ; 3-$ FI with $T_{f}=20 \mathrm{~s}$ 
From the aforesaid each mode has its advantages and disadvantages. Thus FI mode is suitable for multiple mass samples investigation on account of its high mass productivity, that reduces price of analysis and automats it. However analytical FI signal is under the influence of the kinetics of two processes: physical dispersion of the sample's zone in the career flow and electrochemical processes of detecting particles formation, that necessitate of the exacting control of sample residence time in the system and degree of its dilution in the flow.

By batch mode this is out of necessity, as analytical signal is under the influence of detecting particle formation by electrochemical process, that just improves the analytical precision. Sensors in plane gives the opportunity to carry out mass investigation too. But disadvantages of this mode are nonrecoverable and low economic effect at single analysis. High economic effect appears in mass manufacturing only.

So the information about kinetics processes is essential to construct sensors successfully, that under the explanation of the mathematical models.

Obtained results can be used for verification and comparison of experimental data and theoretical results, for determination of $\mathrm{OC}$-sensor parameters for efficient analysis, and to make a choice of the analysis mode.

The author is grateful to Prof. N.N. Rozhitskii for pointing out onto the necessity of solving above mentioned goal of investigation.

\section{References}

1. Clarc L.C., Loys C. Electrode system for continuous monitoring in cardiovascular surgery, Ann. N.Y. Acad.Sci., 102, 1962, p. 29-45.

2. Chaubey A., Malhotra B.D. Mediated sensors, Biosens. Biolectron., 17, 2002, p. 441-456.

3. Masayuki Itagaki, Takahiro Kikuchi, Kunihiro Watanabe Electrochemiluminescence of N-(4-Aminobutil)-ethylisoluminol investigated by electrochemical impedance spectroscopy, Anal. Chem., 15, 1999, p. 755-760.

4. Mell C.D., Maloy J.T. A model for the amperometric enzyme electrode obtained through digital simulation and applied to the glucose oxidase system, Anal. Chem., 47, 1975, p. 299-307.

5. Schulmeister T. Mathematical modelling of the dynamics of amperometric enzyme electrodes, Selective Electrode Rev., 12, 1990, p. 260-303.

6. Robert J. Forster, Conor F. Hogan Electrochemiluminescent metallopolymer coatings: combined light and current detection in flow injection analysis, Anal. Chem., Vol. 72, \#72, 2000, p. 55765582.

7. Kunihito Hayakawa, Yasuhiro Yoneda, Yasuaki Okamoto, Takahiro Kumamaru, Masahiko Ikeda Rapid determination of oil in water using flow injection analysis and IR detection, Analytical Sciences, 15, 1999, p. 803-805.

8. Рожицкий Н.Н., Бых А.И., Красноголовец М.А. Электрохимическая люминесценция: Монография. - Харьков: ХТУРЭ, 2000. — 320 с. 